\title{
SC Teaching Reform on Integrated Business English Courses
}

\author{
Qi Kang
}

English Department, Dalian Neusoft University of Information

Qi Kang.Email: kangqi@neusoft.edu.cn

\begin{abstract}
Student-centered teaching mode has gained great popularity during the recent decades in China. It emphasizes students' active participation throughout the whole learning process. Different from teacher-centered mode of teaching, students are entitled to lead their own learning process and are free to decide when, where and how their learning will be. In Dalian Neusoft University of Information, English department has carried out student-centered teaching reform in Business English course construction. This paper takes the series courses of Integrated Business English as an example to illustrate the designs, implementation and outcomes of SC education reform on Business English majors in Dalian Neusoft University of Information.
\end{abstract}

Keywords: Student-centered, Blended teaching, Case study, Project implementation, Key indicators.

\section{COURSE INTRODUCTION}

In Dalian Neusoft University of Information (DNUI for short), Business English major students are required to learn a series of fundamental courses during the first two years in college. For example, there are the oral English series courses, namely Pronunciation and Communication, Current Issues Discussion, Public Speaking and Debating. The Integrated Business English courses are also a series of fundamental core courses for Business English majors. These courses are an important guarantee for students' effective language acquisition, the enhancement of their practical skills and the application of professional knowledge. The courses also prepare students for the subsequent business and culture course study during the following years in the university. Through training of basic skills in listening, speaking, reading, writing and translating within the cultural and business contexts, students benefit from this SC teaching mode and their comprehensive abilities in business English application have been enhanced.

In the following sections, based on the analysis of SC teaching mode on Integrated Business English series courses, the author makes an introduction of the various designs, the implementation and the outcomes of SC teaching reform in DNUI for business English major students.

\section{STUDENT-CENTERED DESIGN}

\subsection{Student-Centered Teaching}

In the 1930s, American educators began to use the terms teacher-centered and student-centered to describe two different approaches to teaching. In the former teacher-centered teaching mode, teachers have control over all learning activities and tend to do most of the talking in class. It usually takes the form of grammar drilling, academic lectures and direct instructions. In such teacher-dominant classes, students passively spend their time in listening, routinely taking notes and completing assignments to meet teachers' requirements. Their sense of involvement in learning and enthusiasm for knowledge acquisition has been reduced and their academic performance has been negatively influenced.[1] The recent reform of SC teaching, on the other hand, gives students opportunities to participate more actively in all learning activities. Students greatly contribute to the design of their own study. They make decisions on their own learning, hold group discussions and explore topics that greatly interest them. It usually takes the forms of active learning, cooperative learning and inductive learning. Students will enjoy the class more and have a greater understanding of the knowledge. They are more motivated and their peer communication in class is greatly improved. Studentcentered mode fully considers what students need to 
know or what methods would be most effective in facilitating learning for them.

As a pioneer in education reform in China, Dalian Neusoft University of Information has carried out student-centered reform in the course construction since the past few years. As for the Integrated Business English courses, teachers have applied many innovative teaching designs to fulfill the implementation of student-centered teaching reform. Different levels of outcome-oriented project have been designed and blended teaching reform and case study have also been implemented. In the following sections, the author will give an introduction of these designs in details and show how SC teaching improves students' academic as well as applicable achievements.

\subsection{Blended Teaching Reform}

Blended teaching mode refers to the integrated design of before-class, in-class and after-class tasks.[2] It requires teachers to assign online learning tasks together with offline learning ones at different teaching phases. The purpose is to motivate students to learn and make them more involved in class activities so that finally independent learning mode can be gradually formed. Teachers provide students with various learning resources to guarantee a high learning efficiency. And the teaching resources are classified into three levels. For the top students who usually perform well in class, the most challenging tasks are assigned. For those at the preliminary and secondary level, customized resources are prepared for their self-study. Blended teaching is designed to cater to the specific needs of each individual student. With the help of blended teaching mode, course tests at different stages are designed accordingly. There are pretests set at the beginning of each unit teaching, with post-test set when the instruction is over. And there are also two or three periodical tests during the whole semester. Finally, students' acquisition of knowledge and formation of active learning habits are fulfilled. The following table shows some blended teaching designs in DNUI for the Integrated series courses.

For Integrated Business English series courses, there are an overall of eight units in each textbook. Each unit is designed with blended learning activities and covers about 2 weeks' teaching. For each unit, one passage is chosen for intensive reading and another for extensive reading. As for the intensive reading passage, students are required to finish several preview tasks before class. For example, they should master the pronunciation, meaning and application of new expressions before class. Otherwise, they will have difficulty in reading the passage accurately and in understanding the whole passage. Their abilities for language application will be negatively influenced. They are also guided to finish the comprehension tasks that will facilitate them in understanding the text structure and meaning as well.
In-class section is left for teachers to design discussions, presentations and other challenging tasks that need teachers' instructions, such as sentence translation, paraphrasing tasks and drilling on intercultural business communication skills. After class, they should read extensively to improve reading abilities and accumulate extensive knowledge. They should also improve their summary writing ability through practice.

To facilitate the SC teaching reform, DNUI has set up an online learning platform, on which teachers update various forms of learning resources and keep track of students' learning activities. The platform facilitates blended teaching reform with modern education technology. Teachers also use other teaching platforms such as Rain Classroom and Cloud Class, which assist them with multi-functions such as performance assessment, task allocation and online discussion.

In order to assess the outcome of blended teaching reform, the author has conducted a survey. The respondents are mainly students from the author's previous classes. They all have blended-learning experience. The following are some of the major findings. As for the effects of blended reform on learning, $100 \%$ students confirm that it promotes their learning. $85 \%$ students regard it as an effective way to motivate them to learn, while the other $15 \%$ say that it has no obvious effect on them. As for the independent learning ability, 94\% students think blended learning mode has a positive effect on their autonomous learning, while $6 \%$ say that it has no obvious effect. Nearly $80 \%$ of the students regard it an effective way to assist them with better academic performance, while $20 \%$ say that no change has been made to their performance.

To sum up, in most cases, blended teaching mode has a positive effect on motivating students and improving their independent learning ability for a better academic performance.

\subsection{Project Implementation}

Since 2008, Dalian Neusoft University of Information has begun to implement CDIO engineering education mode in teaching. In 2012, it became one of the official members of CDIO International Cooperation Organizations. Together with other prestigious universities, DNUI has made great contributions to the popularity and development of CDIO engineering teaching mode in China. Based on the concept of education creating value for students, the university has creatively fulfilled the localization of CDIO model with an aim to satisfy students' needs for individual development.

The engineering education is set in the context of engineering practice, which refers to the four stages of conceiving, designing, implementing and operating 
through an entire life cycle of engineering processes.[3] Under the influence of CDIO engineering education, English department in DNUI has designed various levels of projects to improve students' acquisition of professional knowledge and enhance their comprehensive applicable abilities. Generally speaking, there are comprehensive projects (leve1), course group projects (level 2), course projects (level 3), unit group projects (level 4) and unit projects (level 5). Projects at each level are designed and set with different purposes for teaching. For example, project of Thesis Writing is a first level project. For this project, students are instructed with thesis writing standards and are required to finish the task of thesis writing through the process of topic selection, topic proposal, paper writing and oral defense. The course of Critical Thinking and Writing has set a third level course project. Students are supposed to make an oral presentation in class to introduce a new issue she or he has followed. They also need to submit a written report about the issue. The course of IT English has set a fifth level unit project. It is designed with in-class writing practice for each unit, which includes asking for help, offering a solution to a problem, promoting a product, asking for a feedback and making complaints, etc.

Under the guidance of CDIO engineering model, all the projects in Dalian Neusoft University of Information are designed to guide students to learn and experience the steps of conceiving, designing, implementing and operating in their learning process as in the real engineering practice.

Integrated Business English courses are also designed with the task of project implementation. These series courses have designed various third level course projects as shown in the following table.

Table 1. Project design

\begin{tabular}{|l|c|}
\hline \multicolumn{1}{|c|}{ Series courses } & Project Design \\
\hline Integrated Business English I & $\begin{array}{c}\text { Topic sentence } \\
\text { writing }\end{array}$ \\
\hline Integrated Business English II & $\begin{array}{c}\text { Sentence } \\
\text { paraphrasing }\end{array}$ \\
\hline Integrated Business English III & Summary writing I \\
\hline Integrated Business English IV & Summary writing II \\
\hline
\end{tabular}

The project design of preliminary Integrated Business English courses mainly refers to the tasks of topic sentence writing and sentence paraphrasing. The purpose of designing these two projects is to enhance students' ability to compose topic sentences under English grammatical rules and to paraphrase key sentences with accurate and appropriate English expressions. For Integrated Business English I, students are required to summarize the main ideas in one or more sentences and present the ideas with great accuracy and appropriateness. For Integrated Business English II, students are taught to use accurate and appropriate expressions to rewrite the original sentences without making any changes to the meaning. For the series courses from III to IV, the focus has been changed into summary writing. Take the course of Integrated Business English III as an example. The textbook covers eight units, from which teachers finally select five for teaching according to the assigned teaching schedule. One text chosen is entitled The Commons and Welfare State. Since Chinese students are not familiar with this topic which indicates a distinctive cultural connotation, teachers design the project aiming to guide students to first have an understanding of the cultural and business background and then summarize it with appropriate paraphrasing techniques. Teachers set certain criteria for the quality of their summary writing, such as accuracy, cohesion and conciseness, which will guarantee the quality of project implementation. The objective to cultivate Business English majors' ability for summary writing has been fulfilled. Meanwhile, teachers also offer other learning resources covering similar topics for students' after-class extensive reading assignment.

\subsection{Case Analysis}

Case study is an in-depth, detailed examination of a particular case (or cases) in a real-world context. It prepares students for the kinds of decisions and dilemmas they will confront later in life.[4] Case analysis functions as a form of student-centered teaching method and has a wide application in education during recent years. Take the course of Integrated Business English II in DNUI as an example. At the beginning of the semester, students are suggested to form into groups. Each group will be invited to prepare and show rounds of oral presentations. They will spend time and energy searching for a theme-related case for analysis. Case selection is done under teachers' guidance or according to group member's preferences.

Case study usually offers students an opportunity to form an extended worldview from which they can get an in-depth understanding of the topics. According to students' willingness to learn, they can be assigned to different groups. There are students who usually prefer to stay in the safety zone in the classroom. It means that they have little difficulty in understanding and following teachers' instructions, but are unwilling to step forward to fulfill a more challenging task. Teachers' task is to encourage them with a supportive design in teaching. Case analysis can be taken as such a support for students to explore new world and improve their ability to apply practical skills in learning. There are several topics which can be found in textbook II. After intensive reading, students will be suggested to make a research on the extended case of language popularization for U1 for example. Students learn that English has become the first choice for business activities. But teachers 
encourage them to go even further to make a research on language popularization, especially Chinese language, which has the most users all over the world. As for Unit 3, the topic is about college education. Students will learn about the function and significance of college education. At the same time, they are suggested to make a research on some Chinese philanthropists who make great contributions to the construction and development of their native country. The example of Chinese Philanthropist Ducong serves as a good example to show the great significance of college education for students, especially the profound influence on their career choice and social service engagement.

\subsection{Core Ability Indicators}

The cultivation of core abilities for Business English majors in DNUI includes such basic abilities as listening, speaking, reading and writing, as well as their communicative abilities in the business environment. All the teaching activities are designed for the fulfillment of these key ability indicators, which are set for the cultivation of students' comprehensive abilities and the enhancement of their applicable abilities. The formative assessment and summative assessment are also designed to analyze and prove the effective cultivation and enhancement of students' abilities.

There are some key ability indicators for Integrated Business English I. Because the course is set at the beginning of students' first year in college, so the basic abilities are put great emphasis on, for example, the abilities in listening, speaking, reading, and writing, etc. The purpose is to lay a solid foundation for students. Textual knowledge is also of great significance since students should learn to analyze the texts and the structures as well, sometimes even the underlying meaning of the passage they learn. By setting these key abilities in the course teaching, both the teachers and the students have a clear picture of their teaching and learning objectives. Through formative and summative assessments, scientific analysis can show the effectiveness of the cultivation of these abilities, which form an effective and positive closed cycle for students' development. So the introduction of key abilities into the course construction is an important part of SC education reform.

\section{CONCLUSION}

Besides all the teaching strategies mentioned above, there are also other reforms that are under way in DNUI, for example, the implementation of holistic education mode, which means the collaboration of all engagement and all dimensional education during the whole process. All the methods above bear features of student-centered teaching and guarantee the prospect for students' comprehensive development.

\section{AUTHOR'S CONTRIBUTIONS}

The author has conducted a thorough research on the SC teaching reform in DNUI for business English majors. Various Student-centered teaching designs have been implemented in course construction. The author will further explore the optimal teaching designs under SC teaching reform and maximize students' potential accordingly.

\section{ACKNOWLEDGMENTS}

Great thanks should be given to the previous researchers who have made great contributions to the development of advanced academic theories and the implementation of innovative education reforms. The author also wants to show gratitude to the teaching faculty in English department in DNUI who have played a crucial role in the fulfillment of SC teaching reforms.

\section{REFERENCES}

[1] GM Morel. Student-centered Learning: Context Needed.[J] Educational Technology Research \& Development, 2021.

[2] Ling Jack. Persuasion-in-teaching: A Phenomenological Study. [J] The Humanistic Psychologist, 1985.

[3] Li Wang, Wei Wang. Teaching Reform Strategies for "Signal and System" Using Flipped Classroom Concept.[J] World Scientific Research Journal, 2020.

[4] MJ Hannafin, SM Land. Technology and Studentcentered Learning in Higher Education: Issues and Practices.[J] Journal of Computing in Higher Education. 2000.

[5] N Rotger. Collaborative Writing at Work: Peer Feedback in a Blended Learning Environment.[J] Education and Information Technologies. 2020.

[6] R Quintana. When Classroom Interactions Have to Go Online: the Move to Specifications Grading in a Project-based Design Course.[J] Information and Learning Science, 2020.

[7] Xiangmin Li. Characteristics and Rules of College English Education Based on Cognitive Process Simulation.[J] Cognitive Systems Research, 2019.

[8] Zhu Lin. Blended Teaching Practice of College English Course Based on Outcome-based Education. [J] Education Research Frontier, 2021. 